certain organo-phosphorus insecticides, including the synthesis of diisopropyl chlorophosphate and diisopropyl fluorophosphate, and the assimilation of carbon dioxide by micro-organisms by means of carbon-14 dioxide. At the University of Ghent the isotope zinc-65 has been used for establishing the distribution constants of zine bromide in liquid-liquid extraction with diethyl ether and diisopropyl ether, carbon-14 has been used to study the influence of dinitrocyclopentylphenol on the metabolism of alcohol in mice, and radioactive iodine has been used for studying the metabolism of iodine in infants suffering from lipoid nephrosis. At the University of Liège, carbon-14 has been utilized for preparing methyl iodide and L-methionine in studying the biological origin of the methyl group of adrenaline and of creatine ; iodine-131 has been used for studying a number of toxic goitres, phosphorus-32 for studying the role of inhibitors of cholinesterase on the penetration of the phosphate ion in respiratory organs of the mussel, and carbon-14 for examining the metabolism of cestrone in the rabbit.

At the University of Louvain rubidium- 86 has been used in studies of the beta-gamma angular correlation of this element, carbon-14 in studies of the decomposition of organic matter in the soil, and at the Royal Military School various studies, by means of chlorine-36 and iodine-131, have been made of heterogeneous reactions in the gaseous phase. At the State Agronomic Institute at Gembloux phosphorus-32 has been used in research on its eventual toxic effect on the development of the mycelium of mushrooms and in the chemical separation of phosphorus compounds such as phospholipoids, nucleoproteins, mineral compounds soluble in water and mineral compounds soluble in acids. In clinical work, gold-198 was utilized in three cases at the Centre for Tumours and Physical Medicine, iodine131 in the treatment of thyrotoxicosis, while in industry iridium-192, cobalt-60 and cæsium-137 have been applied in the radiography of steel and in the detection of welding faults, and thallium-204 has been used in experiments on the elimination of static charges.

\section{THE AFRICAN WILD DOG}

$\mathrm{T}$ HE African wild dog, or hunting dog, Lycaon pictus, is a distinct species and is neither related to any domestic breed nor does it appear to be the forerunner of any known type of domestic dog: there are certain structural differences, such as the absence of dew-claws. According to R. M. Bere, the dogs stand about twenty-six inches at the shoulder and measure about four feet from nose to tip of bushy tail (Oryx, 3, No. 4; May 1956). The colour is variable, but is similar to that of a normal 'Alsatian' (German shepherd dog), the animal being covered to a greater or lesser degree with black, yellow or white blotches. A notable feature is the large upstanding, rounded ears. There are recorded cases of wild dogs having been successfully tamed; but an objectionable smell renders them somewhat unpleasant as household pets.

Wild dogs hunt in packs, killing wantonly far more than they need for food, and by methods of the utmost cruelty : Lycaon does not kill quickly as the lion does, but often starts to devour his antelope victim bafore life is extinct. They do more damage than almost any other of the Carnivorae; when they enter a particular stretch of country the disturbance they cause is so great that, for the time being, all the buck are driven out. The absence of antelope from an area is often the first sign of the wild dogs' presence. A particularly unpleasant characteristic is that they will, without hesitation, turn upon any member of the pack that falls by the way through wound or sickness and show no reluctance to consume their own kind.

When the Uganda National Parks were established it was considered necessary, as had been the case elsewhere, to shoot wild dogs in order to give the antelope opportunity to develop their optimum numbers. Fortunately, only a few wild dogs have had to be destroyed, and their number in the parks does not seem to be particularly large. Their habits do not allow them to stay for long in any one place, for they would starve if they did so: the wild dog packs create their havoc and move on.

The shooting of wild dogs has been questioned recently on the ground that, if persisted in, it would result in a disturbance of the balance of Nature. It was argued that should the antelope increase beyond a reasonable limit, the inevitable result would be starvation due to over-stocking and over-grazing. On balance it appears clear that, provided the packs do not increase beyond a reasonable size, they should not be interfered with. With wild animals generally, the rate of breeding and the percentage of those born to reach maturity is, in the absence of predators, largely controlled by the food supply. Generally speaking, the infant mortality among the Carnivorae seems relatively high, so that unless the food supply becomes abnormally easy, numbers just about maintain themselves.

\section{THE SWEDISH FOREST SERVICE}

THE forests of Sweden have played almost as important a part in Britain as in Sweden itself during the last half of the nineteenth century and the first half of the present, and it is not inappropriate, therefore, that the Swedish Forest Service should have published in English a handsome booklet on the development of the forests in relation to the Service*. It was the change in materials used for construction in Britain, especially for ships and buildings, which gave rise to a large demand for coniferous timbers, and Sweden seized the opportunity to exploit its large areas of coniferous virgin forests; until then the chief commercial home demand was for charcoal for the mineral industry. Swedish exports to Britain largely increased after the latter took off the import duty on softwoods in 1866 . In fact, with its increasing industrial activity and increasing demands for pit wood for the coal mines, building timbers and paper pulp, Britain was lulled into a false sense of security; plans for starting afforestation in Britain, the subject of royal commissions, committees, etc., came to nothing, and by the end of the nineteenth century Sweden had built up a very prosperous export trade.

The early history of Swedish forests, though on a much larger scale, was similar to that of Britain to a great extent. In early times the king owned large areas, which were used for hunting purposes, and claimed all waste land. Then came a period in the

* The Swedish Forest Service. Pp. 44. (Stockholm: Swedish Forest Service, 1956.) 
Middle Ages when the Church and the nobles owned much of the forests. At length, with the Reformation, Gustavus V confiscated all the Church property, and gradually it became the rule that all forests not in private ownership and used for the estates belonged to the State. When the foreign demand arose during the past century, the State again gave away large areas of forests to private people and timber merchants, and heavy unrestricted exploitation took place. A Forestry Institute had been founded in October 1828 by Israel Adolf von Strom, regarded as the 'father' of Swedish forestry, with the object of arousing interest in forestry throughout Sweden. The Institute became known later as the Swedish State College of Forestry, which held its centenary in 1928.

Sweden is divided for forestry purposes into three parts-northern, central and southern. The greater part of the State forests are in the north, where the soils are much poorer and, for climatic reasons as well, the growth is much slower. The Forest Service dates back to the seventeenth century, the duties then being to supervise royal hunting and to keep to the regulations as regards felling and selling forest produce by the people. In 1859 a Board of Forestry was establisbed and six forestry schools were founded. Private forests were still outside any legislation. In 1883 the agricultural sections of State lands were placed under the Board of Forestry, and the name of the Board was changed to Board of Crown Lands and Forests. Under the Board came forests, the Forest Research Institute founded in 1902, and forest education, both higher and lower.

The most rapid progress was made in forest administration from the beginning of the century, one of the chief steps being the reorganization of the accounting system. Separate accounts officers were established in different parts of the country, and this allowed the forest officer, now relieved of much 'paper' work, to devote more time to his forests in the open, instead of chiefly in the office. The Forest Service had been a trading department, and this was changed by the formation of the Royal Swedish State Forestry Industries, Ltd., which is owned by the Forest Service; the supervision of private forests and public non-State forests was placed under a Royal Board of Private Forestry. The staff of the Forest Service is very much on the lines of that in Britain, as also is the forestry education. One difference is that a much greater latitude is given to the district forest officer, who is made responsible, within the administrative policy laid down, for all the work within his charge and has not constantly to refer to superior authority. E. P. StebBing

\section{THE ROSS GLACIER}

\section{By RICHARD BROWN}

$I^{\mathrm{N}}$ $\mathrm{N}$ view of the forthcoming work in the areas around the antarctic during the International Geophysical Year of $1957-58$, it may be appropriate to review some observations on the Ross Glacier in South Georgia, Falkland Islands Dependencies, which date back to the first International Polar Year.

The island of South Georgia, some 120 by 25 miles (the long axis lying north-west-south-east), lies some 1,000 miles east of Cape Horn, between latitudes $\mathbf{5 4}^{\circ}$ and $55^{\circ} \mathrm{S}$. It is entirely mountainous, the axial chain rising to almost $10,000 \mathrm{ft}$.
The Ross Glacier (lat. $54^{\circ} 33^{\prime} \mathrm{S}$., long. $36^{\circ} 05^{\prime} \mathrm{W}$.) is the chief feature of Royal Bay, a large inlet on the north-east coast of the island. It presents a wide front of ice cliff approximately $120 \mathrm{ft}$. high, calving into the water at the head of the bay, and rises to a low pass (the Ross Pass) which leads downwards by equally gentle slopes on the far side as the Brogger Glacier, to meet the sea on the south-west coast, where it calves into the waters of Undine South Harbour. The distance from coast to coast is almost 15 miles.

The German Transit of Venus Expedition had its base hut and observatory on the north side of Royal Bay during the years 1882-83. The party was a very hard-working one, for, in addition to the astronomical observations, work was also carried out in the fields of geology, zoology and botany. A survey of the area was made, and plots of the position of the ice front were made on four occasions: August 1882, December 1882, May 1883 and August 1883. There was recession between these dates, particularly the last two, amounting to a total of almost half a mile1.

The next visitor to Royal Bay was Otto Nordenskjöld in 1902.

Before work in the Cumberland Bay area farther to the north, the surveyor of the Expedition, S. A. Duse, plotted the new position of the snout in April 1902. It was found that the ice-front stood in a position in advance of that of August 1882. The advance had been in excess of the total retreat noted by the German party. Nordenskjöld summarized his own and the German expedition's findings in his book "Antarctica",

In December 1951 the area was visited by the South Georgia Survey, led by Duncan Carse. The true left bank of the glacier was used as a sledge route to the Ross Pass and the interior. The area was accurately mapped; but no glaciological work was undertaken ${ }^{3}$. In January 1955 the position of the snout was plotted by members of the British South Georgia Expedition, as part of the glaciological programme. This new position showed a large embayment near the south edge, and a considerable retreat of the north part of the snout. So far as comparison of the plans (on varying scales) permits, it would appear that the cliffs occupied a somewhat intermediate position between those of May and August 1883, and a considerable retreat from the 1902 position. On the south side of the glacier, recent moraines exist up to $600 \mathrm{ft}$. from the snout, and it may be that there was further advance after the 1902 maximum, for the 1882-83 and 1902 positions show little variation of the glacier's position on the shoreline, the main variation being in the position of the ice-cliffs in the water.

The glacier is derived from two main accumulation areas: that to the north from the peak ("Sunset Pealk'; not an officially recognized name) at the south end of the Allardyce Range and the Ross Pass snowfields, and that to the south from the Salvesen Range, including a separate lobe which produces a large area of complex crevassing on the south side of the main stream of the glacier near the snout.

These two areas are of different altitude; that of the Allardyce is of a lower altitude than that of the Salvesen side by some $1,500 \mathrm{ft}$. on average.

In late January 1955 the summit of the Ross Pass $(1,800 \mathrm{ft}$.) was surfaced with large irregular patches of firn, with intervening areas of bare hummocky ice. Ablation was proceeding (and continued elsewhere in the island at similar altitudes until March) and it 